\title{
PELATIHAN TEKNISI JARINGAN INTERNET UNTUK MENINGKATKAN JIWA KEWIRAUSAHAAN SISWA SMK (IbM)
}

\author{
Yani Maulita $^{1}$, Katen Lumbanbatu ${ }^{2}$ \\ 1, 2 STMIK KAPUTAMA,Binjai \\ "yassa_26@ymail.com
}

\begin{abstract}
Abstrak
Jumlah pengangguran terbesar saat ini adalah tamatan SMA/SMK/SMA, hal ini terkait dengan semakin tinggiya tingkat pendidikan masyarakat, yang umumnya telah tamat SLTA melanjut ke perguruan tinggi. Perkembangan teknologi dan informasi membawa dampak ke dunia pendidikan, sehingga minat masyarakat untuk memilih jurusan bidang informatika mencakup Teknik Komputer Jaringan, Audio Visual, Design Grafis, Teknik Informatika, dll terus meningkat baik tingkat sekolah menengah maupun tingkat perguruan tinggi. Banyaknya peminat jurusan bidang informatika mengakibatkan kuatnya persaingan para lulusan untuk mendapatkan pekerjaan, sehingga perlu ada upaya penanggulangan untuk meningkatkan skill siswa-siswi dan lulusan jurusan bidang informatika agar tidak semata-mata ingin mencari perkerjaan tetapi mampu mandiri bewirausaha dan membuka lapangan kerja. STMIK Kaputama merupakan perguruan tinggi pertama dalam bidang informatika di Kota Binjai. Kaputama merupakan singkatan dari Karya Putra Utama, sesuai dengan tugas utamanya melaksanakan tridharma perguruan tinggi maka dosen STMIK Kaputama terus melakukan kegiatan pengajaran, penelitian dan pengabdian masyarakat, melihat kuatnya persaingan lulusan SMK masyarakat Kota Binjai dan Kabupaten Langkat, dosen STMIK Kaputama sangat berkompeten dalam bidang informatika dan merasa terpanggil untuk melaksanakan pengabdian masyarakat untuk meningkatkan skill siswa-siswi SMK Swasta YPIS Maju Binjai dan SMK Swasta Harapan Stabat dalam bentuk pelatihan teknisi komputer dan ahli jaringan internet dalam meningkatkan jiwa kewirausahaan mandiri siswa-siswi. Dengan adanya pelatihan teknisi komputer dan ahli jaringan internet, diharapkan siswa-siswi SMK Swasta YPIS Maju Binjai dan SMK Swasta Harapan Stabat dapat lebih meningkatkan skill dan jiwa wirausahaan sehingga mereka mampu berwirausaha sekaligus membuka lapangan kerja secara khusus untuk dapat menerima perbaikan komputer dan membangun jaringan warnet, jaringan internet perkantoran dan jaringan internet masuk desa. Selain adanya jiwa wirausaha, masyarakat juga terbantu khususnya pedesaan agar percepatan informasi dan komunikasi dapat lebih meningkat.
\end{abstract}

Kata Kunci: Ahli-Jaringan, Internet, Jaringan-Komputer, SMK-Wirausaha, Teknisi-Komputer.

\section{PENDAHULUAN}

Kota Binjai yang memiliki luas 9.023,62 Ha $( \pm 90,23 \mathrm{Km} 2)$ terdiri dari 5 (lima) Kecamatan dan 37 (tiga puluh tujuh) Kelurahan. Penduduk Kota Binjai berjumlah 261.490 jiwa, terdiri dari 130.551 laki-laki dan 130.939 perempuan dengan kepadatan penduduk 2.898 jiwa/km2 dan rata-rata 4,34 jiwa per
Rumah Tangga (data tahun 2014). Kota Binjai sebagai Kota jasa, Perindustrian, Perdagangan dan Pemukiman telah berupaya memacu laju pertumbuhan Pembangunan yang mendukung Pertumbuhan Pembangunan yang mendukung Pertumbuhan Ekonomi Kota Binjai. Laju pertumbuhan Pendapatan Domestik Regional Bruto (PDRB) Kota Binjai atas dasar harga berlaku tahun 2014 sebesar 11,36 persen. Hal ini menunjukkan peningkatan jika dibandingkan dengan tahun sebelumnya yaitu sebesar 10,81 persen pada tahun 2013. Laju pertumbuhan ekonomi Kota 
Binjai atas dasar harga konstan pada tahun 2014 sebesar 5,83 persen. Hal ini menunjukkan penurunan sedikit jika dibandingkan dengan tahun 2013 yaitu sebesar 6,01 persen. Secara umum, tiga sektor yang paling dominan dalam pembentukan total PDRB Kota Binjai adalah sektor perdagangan besar dan eceran, reparasi mobil dan sepeda motor, diikuti sektor industri dan sektor konstruksi.

(Sumber:

http://www.binjaikota.go.id)[1]

Berdasarkan angka hasil Sensus Penduduk tahun 2010, penduduk Kabupaten Langkat berjumlah 967.535 jiwa dengan kepadatan penduduk sebesar 154,48 jiwa per $\mathrm{km} 2$. Sedangkan laju pertumbuhan penduduk Kabupaten Langkat pada tahun 2010 dibandingkan tahun 2000 adalah sebesar 0,88 persen per tahun. Untuk tahun 2013 berdasarkan hasil proyeksi penduduk Kabupaten Langkat 978.734 jiwa. Jumlah penduduk terbanyak terdapat di Kecamatan Stabat yaitu sebanyak 83.273 jiwa dengan kepadatan penduduk 765,03 jiwa per $\mathrm{km} 2$, sedangkan penduduk paling sedikit berada di Kecamatan Pematang Jaya sebesar 13.131 jiwa. Kecamatan Binjai merupakan kecamatan yang paling padat penduduknya dengan kepadatan 1.021,93 jiwa per $\mathrm{km} 2$ dan Kecamatan Bahorok merupakan kecamatan dengan kepadatan penduduk terkecil yaitu sebesar 36,57 jiwa per km2.( Sumber : http://langkatkab.bps.go.id/ ) [2]

Program studi Teknik Komputer Jaringan di SMK Swasta YPIS Maju Binjai dan SMK Swasta Harapan Stabat dalam proses belajar mengajar mengikuti kurikulum sesuai dengan standard pemerintah, sehingga siswa-siswi memiliki kemampuan dasar untuk design dan instalasi jaringan. Mengingat saat ini pendidikan dalam bidang ilmu komputer yang sangat berkembang pesat baik dalam tingkat sekolah menengah maupun tingkat perguruan tinggi, menjadikan tantangan bagi lulusan SMK karena banyaknya kompetitor dan kuatnya persaingan baik dari tingkat SMK maupun dari tingkat lulusan perguruan tinggi.Secara umum siswa-siswi SMK memiliki pengetahuan umum tentang arsitektur jaringan, topologi, Ip addres, Mikrotik, pengkabelan, setting miktorik, wifi. Dalam hal konfigurasi mereka hanya mampu untuk setting maupun design untuk personal. Selain kemampuan dalam teknologi jaringan komputer, siswa-siswi juga memperoleh pengetahuan dalam bidang wirausaha yang di dapat dari bangku sekolah (Pardede, 2016)[3].

Melihat kemampuan siswasiswi dalam hal kemampuan dasar untuk membangun jaringan komputer serta pengetahuan dalam bidang wirausaha, sehingga siswa- SMK Swasta YPIS Maju Binjai dan SMK Swasta Harapan Stabat sangat potensial untuk dikembangkan sehingga mampu berwirausaha dalam hal membangun infrastruktur jaringan komputer dan internet, mampu membangun jaringan internet di warnet dan internet masuk desa. Mengingat sekarang ini perkembangan dunia infomasi dan komunikasi sangat pesat, tidak hanya diperkotaan tetapi juga sampai ke pedesaan.Wirausaha dalam hal penyediaan jasa pembangunan jaringan internet sangat menjanjikan.

\section{METODE PELAKSANAAN}

Untuk lebih jelasnya metode pelaksanaan pengabdian IbM yang diusulkan dapat di laksanakan dalam beberapa tahap (Faradisa, 2015)[4], yang digambarkan pada gambar 1. Flowchar Pelaksanaan dibawah ini : 


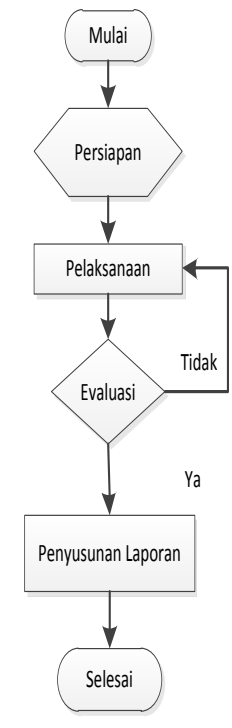

Gambar 1. Flowchart Pelaksanaan

Tahapan kegiatan pengabdian kepada masyarakat ini melalui beberapa tahapan, meliputi persiapan, pelaksanaan dan evaluasi.

\section{Persiapan}

Tahap persiapan dilakukan beberapa kegiatan, yaitu :

* Survei tempat pelaksanaan kegiatan, dalam hal ini SMK Swasta YPIS Maju Binjai dan SMK Swasta Harapan Stabat.

* Wawancara dilakukan dengan Kepala Sekolah SMK Swasta YPIS Maju Binjai yaitu Ibu Sri Rezeki Sutrisnawati, S.Pd dan Kepala Sekolah SMK Swasta Harapan Stabat yaitu bapak T.M.T Wahyu Amami, M.Pd dengan tujuan untuk mengumpulkan data siswa dan terkait dengan keutuhan-kebutuhan pelatihan yang direncanakan

* Pembuatan modul, modul pelatihan dibagi menjadi tiga belas bagian sesuai dengan pelaksaan kegiatan

\section{Pelaksanaan Kegiatan}

Rencana pelaksanaan kegiatan dibagi menjadi beberapa tahap, yaitu (Pardede, 2016)[5] :

1. Pelatihan Perakitan Komputer, Install Sistem Operasi pada client,
Konfigurasi interface jaringan dan Mikrotik, Konfigurasi IP Addres

2. Pelatihan Konfigurasi Gateway, Konfigurasi DNS Server, Konfigurasi NAT, Konfigurasi DHCP, Subnetting

3. Pelatihan Membangun Server, Membangun Proxy, Membangun Firewall, Management Bandwidth.

4. Pelatihan Kofigurasi dan instalasi jaringan Warnet

5. Pelatihan Konfigurasi dan instalasi jaringan perkantoran

6. Pelatihan Konfigurasi dan instalasi jaringan internet desa

\section{Evaluasi}

Tahapan ini dilakukan untuk mengetahui tingkat keberhasilan kegiatan, sehingga dapat dilakukan penyempurnaan apabila ditemui kekurangan-kekurangan selama kegiatan pelatihan dilaksanakan [6][7].

\section{Rancangan Evaluasi}

Evaluasi ini bertujuan untuk mengetahui apakah terdapat peningkatan

kemampuan siswa setelah dilakukannya pelatihan.

Evaluasi dilakukan dengan dua cara meliputi :

a. Pemberian Tugas :

$>$ Membuat sebuah rancangan pembangunan internet perkantoran, dengan menjelasakan gambaran jaringan dan seting ip dan internet

$>$ Membuat sebuah rancangan pembangunan internet desa, dengan menjelasakan gambaran jaringan dan seting ip dan internet

b. Ujian Praktikum

$>$ Trouble shooting komputer

> Perakitan komputer dan instalasi komputer

$>$ Instalasi jaringan dan internet

c. Kuisioner :

Dimaksudkan untuk mengetahui pendapat dari peserta pelatihan mengenai kegiatan ini, sehingga dapat diketahui apakah tujuan dari kegiatan ini sudah tercapai atau belum.

d. Penyusunan Laporan

Penyusunan Laporan terbagi menjadi dua laporan kemajuan dan laporan hasil. 


\section{HASIL DAN PEMBAHASAN}

Pengabdian IbM Pelatihan Teknisi Komputer Dan Ahli Jaringan Internet Dalam Meningkatkan Jiwa Kewirausahaan Mandiri Siswa SMK Swasta YPIS Maju Binjai dan SMK Swasta Harapan Stabat dilaksanakan sejak bulan Juni 2017 . Adapun kegiatankegiatan yang telah dilakukan adalah sebagai berikut :

1. Sosialisasi akan diadakannya kegiatan pengabdian IbM pada Kepala Sekolah dan siswa SMK oleh tim pengabdian

2. Peninjauan lokasi tempat pendirian tiang pipa pemancar Akses Poin pada kedua mitra pengabdian pada SMK Swasta YPIS Maju Binjai dan SMK Swasta Harapan Stabat

3. Peninjauan tempat untuk kegiatan pelatihan dalam hal pengecekan ketersediaan alat- dan perangkat yang dibutuhkan selama kegiatan pelatihan kepada mitra pengabdian

4. Identifikasi alat-alat yang dibutuhkan oleh mitra pengabdian

5. Mempersiapkan kegiatan pelatihan kepada mitra pengabdian tentang materi pelatihan.

6. Melaksanakan kegiatan pelatihan pengabdian : Perakitan Komputer, Install Sistem Operasi pada client, Konfigurasi interface jaringan dan Mikrotik, Konfigurasi IP Addres, Konfigurasi Gateway, Konfigurasi DNS Server, Konfigurasi NAT, Konfigurasi DHCP, Subnetting, Membangun Server, Membangun Proxy, Membangun Firewall, Management Bandwidth.

7. Publikasi kegiatan pada Koran Metro Bijai-Langkat secara cetak dan online

\section{Rencana Tahapan Berikutnya}

Adapun rencana tahapan berikutnya yang akan dilakukan adalah :

1. Memantau perkembangan siswa-siswa SMK Swasta YPIS Maju Binjai dan SMK Swasta Harapan Stabat yang telah mendapatkan pelatihan.

2. Melalui grup IbM yang telah dibuat pada group facebook diharapkan menjadi ajang komunikasi antara siswa dan tim pelaksana pengabdian, sehingga pembimbingan dan pembimbingan dapat terus dilaksanakan.

3. Melakukan pendampingan setelah dilakukan pelatihan agar sesuai dengan harapan siswa-siswa dapat mendirikan usaha atau bisnis penjualan koneksi internet pada desa.

4. Melakukan publikasi proseding dan jurnal nasional terkait dengan kegiatan Pengabdian IbM Pelatihan Teknisi Komputer Dan Ahli Jaringan Internet Dalam Meningkatkan Jiwa Kewirausahaan Mandiri Siswa SMK Swasta YPIS Maju Binjai dan SMK Swasta Harapan Stabat.

5. Melakukan testing penyerapan pengetahuan yang didapat oleh siswasiswa SMK Swasta YPIS Maju Binjai dan SMK Swasta Harapan Stabat yang telah mendapatkan pelatihan, dan selanjutnya menerbitkan sertifikat pelatihan.

\section{KESIMPULAN}

Dari kegiatan pengabdian pada masyarakat ini dapat disimpulkan bahwa:

1. Pengetahuan dan pemahaman siswasiswi SMK Swasta YPIS Maju Binjai dan SMK Swasta Harapan Stabat pada setiap sesi pelatihan menjadi meningkat.

2. Keinginan siswa-siswi SMK Swasta YPIS Maju Binjai dan SMK Swasta Harapan Stabat untuk berwirausaha meningkat, khususnya untuk membangun warnet milik sendiri dan menjual koneksi internet pada desa dengan memanfaatkan koneksi akses poin yang telah dipelajari pada saat pelatihan. 


\section{SARAN}

Mengingat besarnya manfaat kegiatan pengabdian pada masyarakat ini, maka selanjutnya perlu:

1. Mengadakan pelatihan serupa pada siswa-siswi SMK yang berbeda serta wilayah jangkauan SMK yang lebih luas.

2. Adanya kesinambungan dan monitoring program pasca kegiatan pengabdian ini sehingga siswa-siswi SMK Swasta YPIS Maju Binjai dan SMK Swasta Harapan Stabat dapat mempraktekan keahlian yang diperoleh selama pelatihan di wilayah desa masingmasing.

\section{UCAPAN TERIMA KASIH}

Kami menyampaikan terima kasih yang sebesar-besarnya kepada Direktorat Riset dan Pengabdian Kepada Masyakat (DRPM) Ditjen Penguatan Riset dan Pengembangan Kementerian Riset, Teknologi, dan Pendidikan Tinggi atas dukungan dana berupa hibah pengabdian Iptek bagi Masyarakat (IbM) tahun anggaran 2017. Kami juga mengucapkan terimakasih kepada mitra SMK Swasta YPIS Maju Binjai dan SMK Swasta Harapan Stabat atas pelaksanaan kegiatan pengabdian ini.

\section{DAFTAR PUSTAKA}

[1] http://www.binjaikota.go.id), diakses 25 April 2016.

[2] I. Adan and J. Resing, "Queueing Theory," Technology, vol. 15, no. x, p. 180, 200 http://langkatkab.bps.go.id, diakses 25 April 2016.

[3] A. M. H. Pardede and Novriyenni, "PELATIHAN JARINGAN UNTUK MEMBANGUN JARINGAN WARNET, PERKANTORAN DAN INTERNET DESA ( IbM )," in Seminar Nasional Inovasi dan Teknologi Informasi (SNITI-3), 2016, no. November, pp. 11-12.

[4] I. S. Faradisa, Y. Wahyuni, and F. T.
Industri, "IBM Pelatihan dan

Pendampingan Pembuatan Media Pembelajaran Interaktif untuk Guru Sekolah," Pros. Semin. Nas., pp. 270 277, 2015.

[5] A. M. H. Pardede and Novriyenni, "PELATIHAN PERAKITAN KOMPUTER, INSTALL SISTEM OPERASI DAN PEMASANGAN JARINGAN LOKAL DAN INTERNET UNTUK

MEMBANGUNJARINGAN WARNET, PERKANTORAN DAN INTERNET DESA DALAM MENINGKATKAN KEMANDIRIAN SISWA SMK TUNAS PELITA DAN SMK ABDI NEGARA KOTA BINJAI," TECHSI-Jurnal Tek. Inform., vol. 8, no. 2, pp. 18-25, 2016.

[6] S. I. Faradisa,S.I and Santi,F.W. dan Wahyuni,Y. 2015, "IbM Pelatihan Dan Pendampingan Pembuatan Media Pembelajaran Interaktif Untuk Guru Sekolah Dasar Kelurahan Tasikmadu Dan Kelurahan Tunjungsekar Kotamadya Malang,", PROSIDING SEMINAR NASIONAL "RESEARCH MONTH" 2015 "Sinergi Hasil Penelitian dan Pengabdian kepada Masyarakat untuk Menumbuhkan Kapasitas Inovasi di Bidang Teknologi, Pertanian, Sosial dan Ekonomi”. ISBN:978-602-0856-43-8.

[7] S. H. Fitriasih and Utami,Y.R.W. dan Kustanto, 2009 "Pelatihan Trouble Shooting Komputer untuk Karang Taruna Desa Banaran Kelurahan Banaran Kecamatan Grogol Kabupaten Sukoharjo", Jurnal Ilmiah SINUS, Vol.7, No.2, ISSN : 1693 1173. 